\title{
Proefschrift
}

\section{Dealing with grief and requesting donation. An international challenge. Effects of the European Donor Hospital Education Programme}

Blok GA (9 oktober 2003). Dealing with grief and requesting donation. An international challenge. Effects of the European Donor Hospital Education Programme. Universiteit Maastricht. Pro- motoren: prof. dr. C.P.M. van der Vleuten, prof. dr. G. Kootstra. Maastricht: Unigraphic; 2003. 206 pagina's. ISBN 90-5681-179-7. Verkrijgbaar bij de auteur.

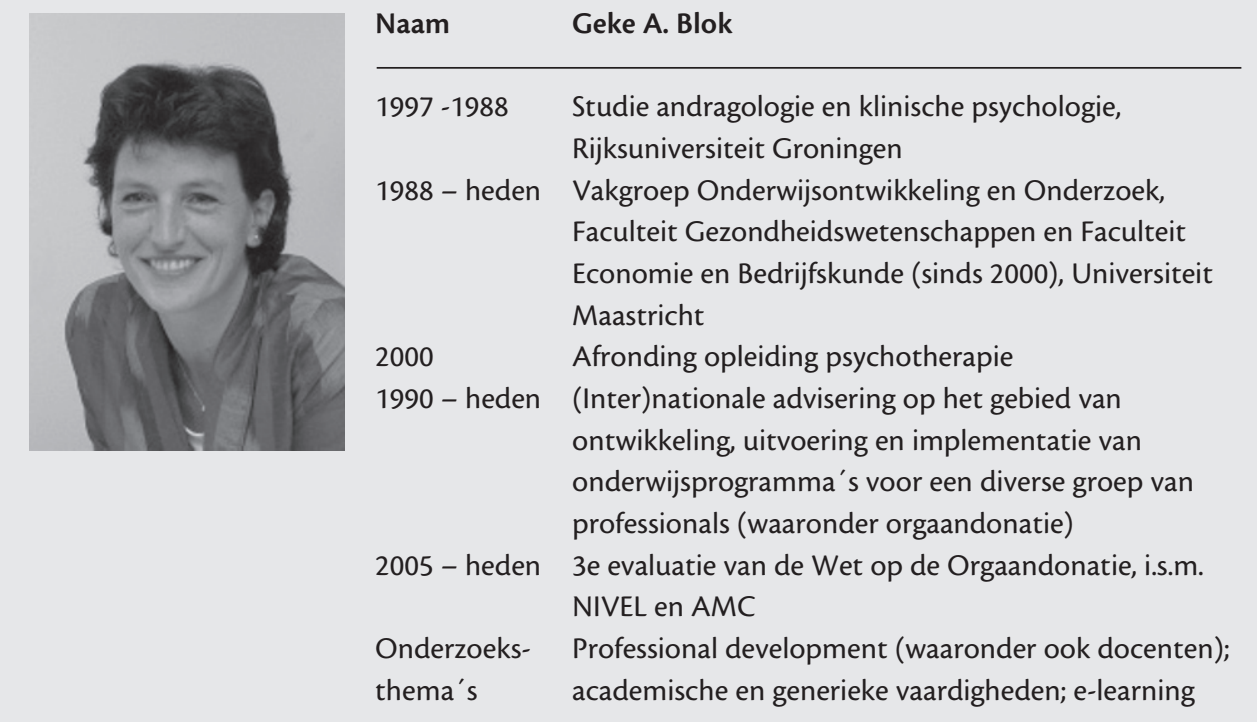

Inleiding: Een van de redenen voor het tekort aan donororganen voor transplantatie is het hoge aantal familieweigeringen. Onderzoek heeft uitgewezen dat de wijze waarop het donatieverzoek wordt gedaan en de kwaliteit van de zorg door artsen en verpleegkundigen van invloed is op de beslissing die nabestaanden nemen ten aanzien van het donatieverzoek. Het European Donor Hospital Education Programme (EDHEP) werd in samenwerking met de Stichting Eurotransplant ontwikkeld om artsen en verpleegkundigen handvatten te bieden voor meer competente communicatie met nabestaanden betreffende overlijden en orgaandonatie. EDHEP is een interactieve workshop van een dag voor gemengde groepen van artsen en verpleegkundigen. EDHEP werd officieel in 1992 in Nederland geïntroduceerd, is in vijftien talen vertaald en in meer dan dertig landen wereldwijd onderdeel van continuing professional education-programma's. In het promotieonderzoek is nagegaan wat het effect is van EDHEP op de competentie (kennis, vaardigheden, attitudes en self-efficacy) van de intensive-carestaf en op de samenwerking in de intensive care, de relatie tussen EDHEP en de tevredenheid van nabestaanden van donoren, en de internationale waardering van EDHEP. (Effecten op kennis en attitudes worden separaat gepubliceerd).

De onderzoeksvragen die in het proefschrift worden beantwoord: 
1. Wat is de mening van deelnemers over de onderwerpen die in EDHEP aan de orde komen en wat zijn de leereffecten?

2. Hoe wordt EDHEP wereldwijd gewaardeerd als onderdeel van professionele educatie en hoe relevant vindt men EDHEP voor de praktijk?

3. Wat is het effect van EDHEP op:

- self-efficacy en (kennis over het gebruik van) communicatievaardigheden van intensive staf met betrekking tot het meedelen van overlijden en het bespreken van orgaandonatie?

- samenwerking in intensive-careteams met betrekking tot het meedelen van overlijden aan en het bespreken van orgaandonatie met nabestaanden?

4. Hoe zijn de thema's die aan de orde komen in EDHEP gerelateerd aan de tevredenheid van nabestaanden van donoren?

Internationale waardering: Uit de resultaten van het onderzoek naar de tevredenheid over en het leereffect van EDHEP blijkt dat het programma internationaal gezien wordt als waardevol voor de professionalisering van de intensive-carestaf op het gebied van orgaandonatie. Men waardeerde vooral de interactieve oefeningen, zoals de simulatiecontacten. De oefening waarin persoonlijke gevoelens ten aanzien van dood aan de orde komen, werd als erg confronterend, maar zeer leerzaam ervaren. Ook de internationale Train-The-Trainer-cursussen (TTT) $(n=234)$ werden qua inhoud en structuur zeer gewaardeerd, ongeacht het land van herkomst. Men gaf aan een goed begrip te hebben gekregen van de doelen en structuur van EDHEP en hoe te werk te gaan in het proces van nationale implementatie. EDHEP is in het merendeel van de landen die geparticipeerd hebben in TTT-cursussen ingevoerd als onderdeel van professionaliseringsprogramma's, soms in aangepaste of meer uitgebreide vorm om tegemoet te komen aan locale omstandigheden en om deelnemers meer gelegenheid te geven te oefenen in simulatiecontacten. De internationale evaluaties geven aan dat de thema's die in EDHEP worden behandeld relevant zijn voor intensive-carestaf over de hele wereld.

Communicatievaardigheden: $\mathrm{Om}$ het effect van EDHEP op de competentie van de intensive-carestaf vast te stellen, werden twee gerandomiseerde prospectieve studies met een follow-up na zes maanden opgezet: een nationale studie in Nederland ( $\mathrm{n}=132)$ en een in het Verenigd Koninkrijk, waaraan 20 ziekenhuizen deelnamen $(\mathrm{n}=64)$. Wat communicatievaardigheden betreft bleek EDHEP zowel tijdelijke als blijvende effecten te hebben; in het Verenigd Koninkrijk bleken artsen direct na deelname beter in staat overlijden mee te delen en donatie aan de orde te stellen. Structurering van de gesprekken en uitleg van de donatieprocedure werden blijven verbeterd. Deze vaardigheden werden gemeten met behulp van een gedragstoets met simulatienabestaanden. In Nederland werden communicatievaardigheden met een papierencasus-toets gemeten, het ging hier om het cognitieve gebruik van communicatievaardigheden. De algemene benadering van een situatie, het probleemoplossend vermogen, toonde een blijvende verbetering; verder traden hier ook vooral tijdelijke effecten op. Uit een validatiestudie in Nederland $(n=28)$, waarin werd nagegaan of de papierencasus-toets de scores op de gedragstoets kon voorspellen, kwam naar voren dat de inschatting van de situatie (diagnostische accuratesse) een redelijke voorspeller bleek voor de totaalscore in de gedragstoets. Voor de afzonderlijke vaardigheden kon geen eenduidige relatie worden vastgesteld. De validatiestudie bevestigende dat gedrag van artsen en verpleegkundigen in dit domein complementair is.

Self-efficacy: Self-efficacyscores toonden een blijvende verbetering. Door de workshop wist men beter hoe overlijden (hersendood) mee te delen, hoe donatie aan de orde te stellen, hoe (emotionele) reacties op te vangen en hoe de donatieprocedure toe te lichten. Men gaf aan dit ook beter te kunnen, ongeacht hun ervaring. Weinig ervaren deelnemers profiteerden het meest.

Deelnemers bleken op termijn meer zelfvertrouwen dan competentie te hebben. De relatie tussen effecten op communicatievaardigheden en self-efficacy toont aan dat deelnemers wisten wat er van hen verwacht werd, zij gaven aan dat ze wisten hoe ze dit moesten doen en dat ze dit ook konden. Ze lieten in de nameting ook zien dat ze in staat waren deze kennis toe te passen en adequaat gedrag te vertonen. Bij follow-up waren deelnemers nog steeds van mening dat ze in staat waren gesprekken met nabestaanden op een goede manier te voeren. Ze lieten dit in de gesprekken echter niet zien.

Samenwerking in de intensive care: In dit onderzoek werden twee groepen van Nederlandse intensive-careafdelingen vergeleken. Eén groep bestond uit afdelingen met een hoog percentage $(\geq 60 \%)$ EDHEP-deelnemers 
(EDHEP-afdelingen) en een groep met een laag EDHEP-percentage $(\leq 15 \%)$. De respons was $65 \%(\mathrm{n}=408)$. Deelname aan EDHEP bleek een significant positief effect te hebben op het teamwork met betrekking tot overlijden en orgaandonatie. In EDHEP-afdelingen was men meer tevreden over de samenwerking; gesprekken met nabestaanden over overlijden werden vaker in het team voorbereid; donatiegesprekken werden vaker in koppels gedaan en er werd vaker een taakverdeling voor deze gesprekken afgesproken; en men was meer tevreden over de implementatie van het donatieprotocol. De doelen van EDHEP met betrekking tot teamwork werden meer dan bereikt. Vooral omdat EDHEP gericht is op individuele professionals en niet op specifieke teams. Wat opviel was dat een derde van de deelnemers aan het onderzoek nooit emotionele steun kreeg van leidinggevenden; dit gold vooral voor de artsen.

Nabestaanden: Nabestaanden die deelnamen aan Nabestaandendagen in 1995, 1998 en 2001, georganiseerd door transplantatiecoördinatoren, vulden een vragenlijst in over de donatieprocedure waarbij zij betrokken waren geweest $(n=387)$. De toename in tevredenheid over de wijze waarop zij door de staf van de intensive care benaderd werden, lijkt erop te wijzen dat orgaandonatieprocedures in Nederland geleidelijk verbeteren. Er konden geen causale relaties worden gelegd tussen EDHEP en de tevredenheid van nabestaanden. In de loop van het decennium bleken nabestaanden tevredener over de opvang bij aankomst, de informatievoorziening en de kwaliteit van de gesprekken waarin overlijden en orgaandonatie aan de orde kwamen. De wijze waarop het overlijden werd meegedeeld verklaarde meer dan 50\% van de variantie in de totale tevredenheid in alle jaren. Op alle gedragsvariabelen die in EDHEP de orde komen, werd toename in tevredenheid geconstateerd. Indirect bevestigen deze resultaten de aanpak die in EDHEP is gekozen.

Goede communicatie leidt niet automatisch tot toestemming als de overledene aangegeven heeft niet te willen doneren. Effecten van EDHEP op donoraantallen kunnen daarom alleen indirect worden vastgesteld en vormden geen onderdeel van dit onderzoek. Elders is echter wel vastgesteld dat implementatie van EDHEP leidde tot toename van het aantal donoren.
Tenslotte: De evaluaties van EDHEP tonen aan dat het programma tegemoet komt aan wensen uit de praktijk. EDHEP is vooral een bewustmakingsprogramma en duurt slechts een dag. Het is daarom opmerkelijk dat EDHEP op de korte termijn zoveel effecten sorteert en zelfs op de lange termijn tot veranderingen in gedrag leidt. Ook bij langer durende trainingen is er sprake van het verdwijnen van initiële effecten. EDHEP heeft een grote impact op de 'beliefs' van deelnemers over hun capaciteiten; verhoogd zelfvertrouwen werd echter niet altijd door daadwerkelijk gedrag bevestigd. Reden om self-assessments kritisch te beoordelen en daarnaast ook naar andere factoren te kijken, zoals in dit geval mogelijke weerstand tot zelfreflectie over dood en orgaandonatie. Ontkenning van de dood en weerstand om hierover bij zich zelf te rade te gaan, lijken niet de juiste attitudes voor professionals die nabestaanden moeten helpen de dood van een geliefde te aanvaarden.

Het aan de orde stellen van orgaandonatie moet niet als een op zich staand gebeuren worden opgevat, maar als een integraal onderdeel van een groter proces. Het nabestaandenonderzoek geeft aan dat opvang, informatie, betrokkenheid en zorgvuldigheid in vooral het slechtnieuwsgesprek belangrijk zijn. Dit wordt bewerkstelligd door goed teamwork. Een team functioneert beter in een veilig werkklimaat waarin het openstaan voor feedback van collega's wordt bevorderd; dit is vooral belangrijk bij emotioneel zware taken, zoals die waarop dit onderzoek betrekking heeft. Goed teamoverleg in een veilig werkklimaat leidt ertoe dat nabestaanden niet worden geconfronteerd met onverwachte persoonlijke conflicten of misverstanden in het team. Integendeel: taken worden verdeeld, men ondersteund elkaar en continuïteit in de zorg is beter gewaarborgd. Dit komt aan alle betrokkenen ten goede.

Dit geldt ook voor onderwijs aan professionals. Het aanleren van kennis en vaardigheden moet afgestemd zijn op de dagelijkse praktijk en niet alleen individuele studieresultaten dienen gemeten te worden maar ook de effecten in de praktijk. Alleen dan kan worden vastgesteld of er sprake is van return-of-investments. Resultaten uit dit outcomeonderzoek (patiënten, team, organisatie en financiën) dienen in het onderwijs geïncorporeerd te worden. 